\title{
The role of gap junctions in inflammatory and neoplastic disorders (Review)
}

\author{
PUI WONG ${ }^{1}$, VICTORIA LAXTON $^{2}$, SAURABH SRIVASTAVA $^{3}$, \\ YIN WAH FIONA CHAN ${ }^{4}$ and GARY TSE G,6 $^{5}$
}

\author{
${ }^{1}$ School of Biomedical Sciences, Li Ka Shing Faculty of Medicine, University of Hong Kong, Hong Kong, SAR, P.R. China; \\ ${ }^{2}$ Intensive Care Department, Royal Brompton and Harefield NHS Foundation Trust, London SW3 6NP; ${ }^{3}$ Faculty of Medicine, \\ Imperial College London, London SW7 2AZ; ${ }^{4}$ School of Biological Sciences, University of Cambridge, Cambridge CB2 1AG, UK; \\ ${ }^{5}$ Department of Medicine and Therapeutics and ${ }^{6} \mathrm{Li}$ Ka Shing Institute of Health Sciences, \\ Faculty of Medicine, Chinese University of Hong Kong, Hong Kong, SAR, P.R. China
}

Received September 9, 2016; Accepted December 23, 2016

DOI: $10.3892 /$ ijmm.2017.2859

\begin{abstract}
Gap junctions are intercellular channels made of connexin proteins, mediating both electrical and biochemical signals between cells. The ability of gap junction proteins to regulate immune responses, cell proliferation, migration, apoptosis and carcinogenesis makes them attractive therapeutic targets for treating inflammatory and neoplastic disorders in different organ systems. Alterations in gap junction profile and expression levels are observed in hyperproliferative skin disorders, lymphatic vessel diseases, inflammatory lung diseases, liver injury and neoplastic disorders. It is now recognized that the therapeutic effects mediated by traditional pharmacological agents are dependent upon gap junction communication and may even act by influencing gap junction expression or function. Novel strategies for modulating the function or expression of connexins, such as the use of synthetic mimetic peptides and siRNA technology are considered.
\end{abstract}

\section{Contents}

1. Introduction

2. Hyperproliferative skin disorders

3. Lymphatic vessel diseases

4. Inflammatory lung diseases

5. Liver injury

6. Neoplastic disorders

7. Conclusion

Correspondence to: Dr Gary Tse, Department of Medicine and Therapeutics, Faculty of Medicine, Chinese University of Hong Kong, 30-32 Ngan Shing Street, Hong Kong, SAR, P.R. China E-mail: tseg@cuhk.edu.hk

Key words: cancer, gap junctions, connexins, mimetic peptides, inflammation

\section{Introduction}

Gap junctions are intercellular channels that mediate both electrical and biochemical coupling through the exchange of ions, second messengers and small metabolites $(1,2)$. Gap junction intercellular communication (GJIC) is essential for regulating cellular differentiation and apoptosis, movement of cells within tissues, and intracellular signalling (3). In excitable tissues, GJIC also governs conduction of electrical signals between successive cells (4-8). Each gap junction is formed by two connexons (hexamers of connexins, $\mathrm{Cx}$ ) that align in the extracellular space (9). Currently 21 members of the human connexin gene family have been identified (10). Some connexin isoforms are cell-type specific, and their expression varies during different metabolic states, such as pluripotent stem cell induction (11), epidermal wound healing (12), epithelial-to-mesenchymal transition (EMT) (3) and pathological states such as hepatitis (13).

Connexin can be found in both excitable and non-excitable tissues. An example of excitable tissue, the cardiac myocardium, has abundant expression of the isoforms Cx30.2, Cx40, Cx43 and Cx45 (14). Their expression levels vary with the region concerned. Thus, $\mathrm{Cx} 40$ is only expressed in the atria, whereas the ventricles show extensive expression of $\mathrm{Cx} 43$ and $\mathrm{Cx} 45$ but not $\mathrm{Cx} 40$. Other connexin isoforms have been detected in many non-excitable tissues (15). Cx43 can be found in breasts, kidneys, skin and lungs. Cx26 is expressed in liver, kidneys and oesophageal epithelium, and Cx32 is found in liver and kidneys (16).

Gap junctions function through two distinct gating mechanisms: membrane voltage-dependent and transjunctional voltage-dependent gating (also known as fast and slow gating) (17). Besides voltage sensitivity, both mechanosensitivity and chemosensitivity have been reported $(17,18)$. For example, connexin activity is influenced by intracellular $\mathrm{Ca}^{2+}$, $\mathrm{pH}$, chemical uncouplers (19), phosphorylation events $(20,21)$, and lipid availability in the immediate environment, including LDL, apo-B (22) and cholesterol (23).

In recent years, there has been a growing interest in the role of connexins in different physiological and pathological 
states, and the use of gap junction modulators in different clinical conditions (24). Apart from modifying gap junction function, interventions can be applied through modulating synthesis, transport, assembly, phosphorylation, and degradation of gap junction proteins (25). It has been shown that gene therapy restores or increases GJIC in transfected cells or 'knock-in' animals $(25,26)$. This review focuses on reviewing the therapeutic applications of gap junction modulators in inflammatory and neoplastic disorders. Potential directions for further investigation and treatment development are also discussed.

\section{Hyperproliferative skin disorders}

Several autosomal dominant hereditary epidermal diseases are attributed to mutations in genes encoding for connexins. These diseases include Vohwinkel syndrome, Bart-Pumphrey syndrome, hystrix-like ichthyosis with deafness syndrome, keratitis-ichthyosis-deafness (KID) syndrome, erythrokeratoderma variabilis, hidrotic ectodermal dysplasia and oculodentodigital dysplasia $(27,28)$.

Cx26 is known to be a significantly upregulated gene in psoriatic patients. In contrast to normal skin, it is detected intensely in keratinocytes in psoriatic plaques $(29,30)$. It has been proposed that $\mathrm{Cx} 26$ regulates epidermal differentiation, more specifically epidermal barrier acquisition. There is therapeutic potential in the reestablishment of skin barrier and inflammatory response regulation, particularly in hyperproliferative skin conditions (31).

Currently, 10 missense substitution mutations in the Cx26 gene are known to cause KID syndrome (32). It has been hypothesized that the abnormally high activity of defective Cx26 hemi-channels allows leakage of cytoplasmic contents, and is therefore detrimental to cell survival and tissue integrity (33). Due to repeated skin fissuring and micro-wounding, bacterial and fungal infections are common, thus requiring a combination of drugs such as emollients, barrier creams, topical keratolytics and anti-microbial agents (33). Retinoic acid is a prospect for novel treatment in hyperkeratotic skin. It unexpectedly causes: i) significant $\mathrm{Cx} 26$ upregulation; ii) $\mathrm{Cx} 43$ upregulation; and iii) increased epidermal thickness (34). Yet, the mechanisms by which elevated $\mathrm{Cx} 26$ expression results in beneficial therapeutic effects in KID syndrome without exacerbating this condition remain unknown. The precise underlying mechanism of action will need to be understood before further testing.

\section{Lymphatic vessel diseases}

Lymphatic vessels collect lymph from excess tissue fluid, return it to the blood circulation and mediate the uptake of lipids, including lipid-soluble vitamins. Previous studies have demonstrated the variable expression of $\mathrm{Cx} 37, \mathrm{Cx} 43$ and $\mathrm{Cx} 47$ during development of the lymphatic system, with the first two segregated at the downstream and upstream sides of valves respectively, while $\mathrm{Cx} 47$ was found in a subset of endothelial cells on the upstream of adult valves (35). It is known that differential expression is involved in initiating the formation and determining the cell polarity of the valve (36); whereas Cx37 and Cx43-knockout mouse models developed defective valves and abnormal thoracic duct formation (35). Several connexin gene mutations have been identified to cause both primary (37) and secondary lymphedema $(38,39)$. Underlying mechanisms and the importance in physiological functioning of the lymphatic system remain unclear; however, future studies may provide answers to developing potential regimens for lymphatic diseases.

\section{Inflammatory lung diseases}

In the respiratory tract, connexins are found in the epithelium, from the airways to alveoli, with regional specific expression patterns (40). At the upper respiratory tract Cx26, Cx30, Cx31, Cx32, Cx37, Cx43 and Cx46 are found, and Cx26, Cx32, Cx37, Cx40, Cx43 and Cx46 are present at lower levels (41). $\mathrm{Cx} 43$ is also found extensively throughout the rest of the lung tissue, including smooth muscles, both alveolar epithelial cell types and even alveolar macrophages (41). Cx32 and Cx43 are both found in cultured human pulmonary artery endothelial cells (42). Gap junctions contribute to mucociliary clearance, surfactant secretion and synchronization of pulmonary vascular smooth muscle contraction (41).

Carbenoxolone, a gap junction uncoupler, was tested in a mouse model of asthma, where it was found to reduce infiltration of inflammatory cells and interleukin production, thereby decreasing lung inflammation (43). It acted by preventing the increase in interleukins 4 and 5 and eosinophils $(43,44)$. These findings suggest that use of gap junction uncouplers can be used in nebulized form for the treatment of asthma.

In a mouse model of allergen-induced airway inflammation, Cx37 expression levels were found to be negatively correlated with airway inflammation, airway responsiveness, and levels of Th2 cytokines (45). Cx37, Cx40 and Cx43 are thought to play a role in regulating vascular resistance and right ventricular function (46). Decreased expression of these connexins are implicated in the pathogenesis of pulmonary arterial hypertension (PAH) by increasing airway inflammation and sensitivity $(41,47)$.

The role of $\mathrm{Cx} 40$ in pulmonary vascular function was explored in an animal model of acute lung injury (48). During the course of lung injury, $\mathrm{Cx} 40$ expression was decreased in a time-dependent manner with increased vascular permeability. The latter was aggravated by the gap junction uncoupler heptanol, which produced abnormal $\mathrm{Ca}^{2+}$ handling in smooth muscle cells. In Cx40-knockout mice, increased inflammation with induced leukocyte infiltration was observed (49). Cx40 was found to mediate anti-inflammatory effects by activating CD73, which reduced adhesion by adenosine production. Another study tested the hypothesis that a reduction in $\mathrm{Cx} 40$ expression may limit acute lung inflammation (50). However, these authors found that the development of acute lung inflammation did not differ between wild-type and Cx40-knockout mice.

Cx43 expression is upregulated in lung epithelium and vascular endothelium (51), and was found to be positively correlated with increased pulmonary vascular permeability in many disease states (41), such as acute inflammation induced by radiation (52) and bacterial sepsis $(53,54)$. In contrast, decreased $\mathrm{Cx} 43$ expression in chronic pulmonary diseases such as cystic fibrosis and idiopathic pulmonary fibrosis, 


\section{Sildenafil in inflammatory lung diseases}

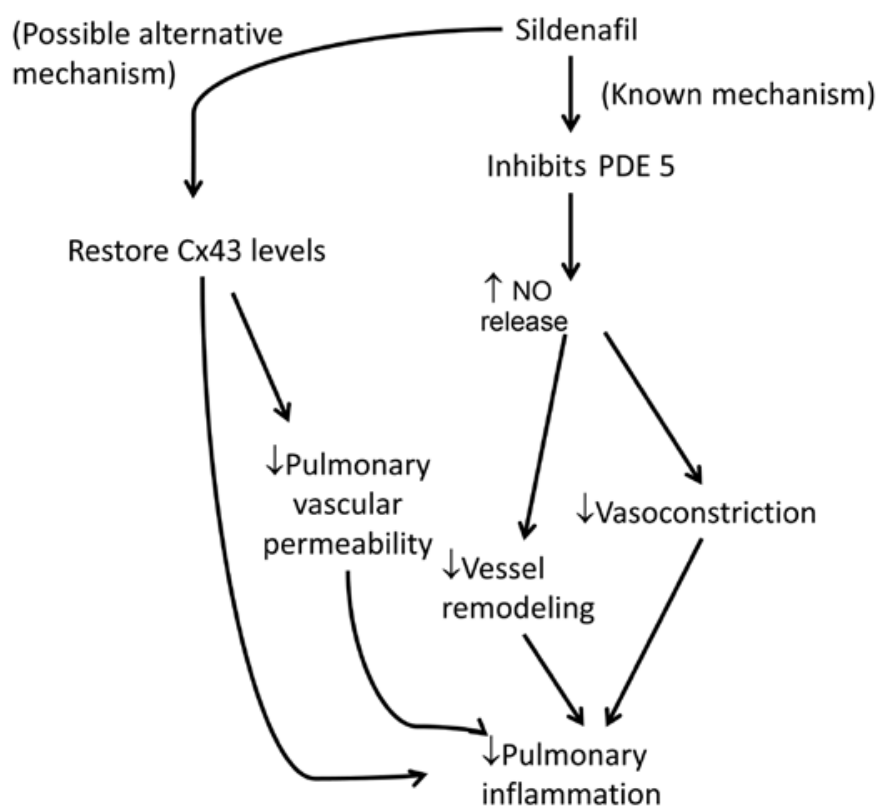

Figure 1. The mechanisms of action of sildenafil in the treatment of pulmonary inflammatory diseases.

was attributed to aberrant $\mathrm{Cx} 43$ transport and reduced $\mathrm{Cx} 43$ mRNA levels, respectively $(55,56)$.

Various pharmacologically active substances have been reported to enhance connexin expression in the lungs. Sildenafil, a phosphodiesterase 5 inhibitor, is a common agent used to treat PAH owing to its ability to vasodilate and suppress adverse vessel remodeling (57). Experiments in a mouse model of PAH suggest that it also acts to restore $\mathrm{Cx} 43$ to normal levels (Fig. 1) (58). Rotigaptide, a synthetic peptide which acts to enhance gap junction function, is currently under clinical trial for preventing cardiac arrhythmias. It is also being investigated for its potential protective effects in pulmonary inflammatory diseases (41). Expression of various connexins in pulmonary endothelial and smooth muscle cells can be interfered with by using siRNA $(54,59)$, which can potentially be exploited to treat pulmonary inflammatory diseases (41).

\section{Liver injury}

Hepatic gap junctions are known to play a crucial role in intercellular communication (60) and local propagation of antiviral immune response signaling (61). In chronic liver disease, Cx32 is lost from the hepatocyte membrane by apoptosis as the condition progresses (62). Cx32-knockout mice exhibited resistance to liver cell death induced by $\mathrm{D}$-galactosamine and carbon tetrachloride (63), but increased predisposition to liver cancer (64). In contrast, Cx43 was induced in the cytoplasm of damaged liver cells, and a Cx43 inhibitor downregulated the activity of caspase-3, a major contributor in the apoptotic cascade (62). The underlying mechanism is therefore suggested to be $\mathrm{Cx} 43$-induced hepatocyte apoptosis regulated by GJIC. Upon Cx32 removal, injured hepatocytes may escape apoptosis and their persistence may pose as a risk factor in carcinogenesis (62). The exact mechanism remains to be eluci- dated; however, there is counter evidence against the notion that $\mathrm{Cx} 43$ directly induces apoptosis $(65,66)$. In addition to acute liver injury, altered levels and localisation of certain connexins such as $\mathrm{Cx} 26, \mathrm{Cx} 32$, and $\mathrm{Cx} 43$ are associated with cholestasis and liver fibrosis (13).

The liver is responsible for the metabolism of drugs, which can often induce liver injury in a dose-dependent manner and produce fulminant hepatic failure (67). Cx32 and Cx40 have been implicated in paracetamol-induced liver injury $(65,68,69)$. Gap junction inhibition was shown to protect against this injury by inhibiting cytochrome P450 enzymes and c-jun $\mathrm{N}$-terminal kinase activation (70) as well as apoptotic signalling (62), thereby preventing fulminant liver failure (71).

\section{Neoplastic disorders}

Hepatocellular carcinoma (HCC) is associated with the presence of $\mathrm{Cx} 43$ expression, while reduced $\mathrm{Cx} 43$ levels have been associated with reduced invasion, migration and metastasis (Fig. 2) (72). However, several studies have demonstrated differing results. In one study $\mathrm{Cx} 43$ overexpression was noted in HCC and in especially rapidly growing cells with limited differentiation (73). In another, induced $\mathrm{Cx} 43$ expression in rat HCC cells reduced the growth rate and even led to cytoskeletal reorganization similar to the effects noted following treatment with all-trans retinoic acid, which induces differentiation (74). It is unclear whether $\mathrm{Cx} 43$ serves as a definitive oncogene or tumour-suppressor gene, or that its activity depends on its expression level. Cx32 displays characteristics of a tumoursuppressor gene, as its removal in rodents led to a significant increase in hepatocarcinogenesis (75).

Lindane (hexachlorocyclohexane) is an insecticide that is also used to induce carcinogenesis in pre-clinical research. It induces Cx43 endocytosis through activation of extracellular signal-regulated kinases and Ser368 phosphorylation, leading 


\section{Anticancer drugs and modulation of Gap junctions}

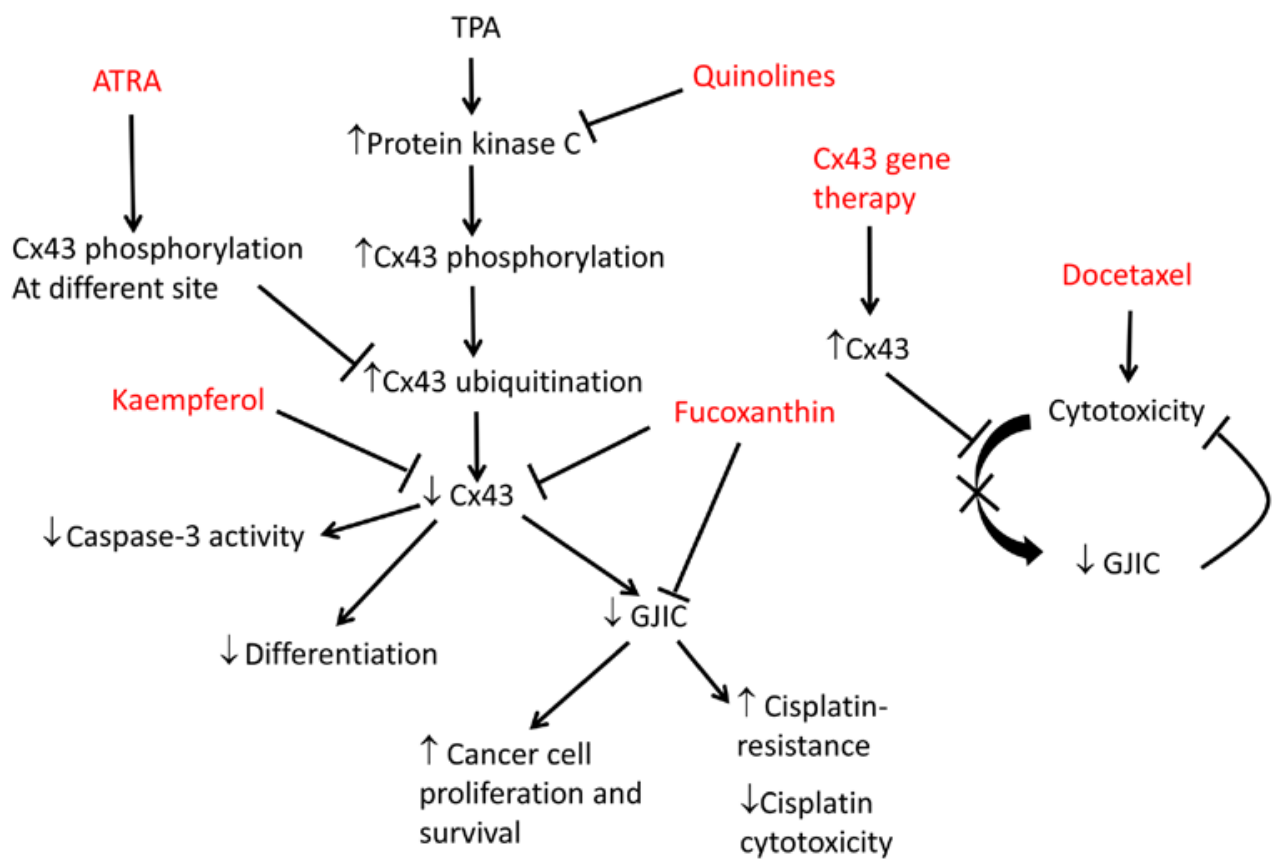

Figure 2. Anticancer drugs and their modulation of the function of gap junctions. TPA, 12- $O$-tetradecanoylphorbol-13-acetate; GJIC, gap junction intercellular communication.

to GJIC uncoupling in liver and myometrial cells $(76,77)$ Oxidation of glutathione was also observed (78). This is thought to contribute to the promotion of neoplastic growth $(77,78)$. Lindane was also found to inhibit GJIC and induce changes in $\mathrm{Cx} 43$ and ZO-1 localisation from the membrane to the cytoplasmic perinuclear region (79). Lindane can be used in further investigations to investigate the mechanisms of carcinogenesis and the involvement of connexins to identify therapeutic targets.

Metastatic breast cancer can be aggressive, metastasizing to distant organs such as the lungs, liver, bones or brain (80). Cx43-mutant mice have reduced $\mathrm{Cx} 43$ levels, extensive mammary gland hyperplasia but delayed onset of palpable tumours (81). Increased metastasis to the lungs was observed when compared to control mice with normal Cx43 levels. Cx43 therefore appears to exert protective effects. Regarding colon cancer, $\mathrm{Cx} 43$ downregulation was found in colon cancer cell lines and in colorectal carcinomas, and was found to be associated with shorter relapse-free and overall survival (82). Normally, Cx43 co-localizes with $\beta$-catenin and negatively regulates the Wnt pathway, mediating apoptosis. When Cx43 levels are reduced, apoptosis of cancer cells is lost.

Several chemotherapeutic agents have been studied for their anti-neoplastic effects, in which connexin proteins have been implicated (83-85). Fucoxanthin, a carotenoid, was found to inhibit tumorigenesis in human cancer cells from colon, prostate, leukemia and cervical epithelium (86). At high doses it inhibits the tumour suppressor p53, thereby promoting apoptosis (87) and inducing cell cycle arrest (88). In hepatic cancer SK-Hep-1 cells, fucoxanthin increased Cx32 and Cx43 expression and enhanced GJIC (84). Kaempferol, an antiflavonoid anticancer agent, promoted the differentiation of partially differentiated colon cancer cells with low Cx43 expression. This was associated with higher levels of Cx43 and phosphorylation status (89).

Quinoline, a gap junction enhancer (90), inhibits protein kinase C (PKC). PKC normally phosphorylates Cx43, and interferes with the interaction between $\mathrm{Cx} 43$ and Nedd4, an E3 ubiquitin ligase. Therefore quinolone application maintains GJIC, thereby suppressing breast cancer cell proliferation and survival (91). Studies found that tumours may develop cisplatin-resistance through loss of GJIC, preventing the drug from spreading among cancer cells $(92,93)$. The firstgeneration quinolone, PQ1, was tested in combination with cisplatin, and was shown to potentiate cisplatin cytotoxicity by a GJIC-dependent mechanism (90). Co-treatment with gap junction-enhancing agents therefore represents a possible approach to target drug-resistant tumours.

12- $O$-tetradecanoylphorbol-13-acetate (TPA), a known tumour promoter, was found to activate the PKC pathway through mimicking diacylglycerol (94), thereby stimulating cell proliferation (95). It opposed the anti-proliferative action of the third-generation substituted quinolone PQ15 in T47D breast cancer cells (83). TPA also displayed similar counteracting effects against PQ1 in SW480 colorectal cancer cells (96). It was also found to induce Cx43 ubiquitination in IAR20 rat liver epithelial cells (97). These findings suggest that PQ15 acts by inhibiting TPA-mediated phosphorylation of Cx43 (83), and quinolones can be versatile anticancer drugs (98).

All-trans retinoic acid is a natural vitamin A derivative that has been widely used in the chemoprevention and chemotherapy of head and neck cancers (99). In addition to its known mechanisms of action such as the regulation of differentiation and proliferation and induction of apoptosis, previous studies have demonstrated that it upregulated $\mathrm{Cx} 43$ phosphorylation 
and restored GJIC in hepatoma HepG2 (100) and oral squamous cell carcinoma cells (101). A new antitumour mechanism was proposed in light of the fact that ATRA restored expression of gap junction proteins $\mathrm{Cx} 32$ and $\mathrm{Cx} 43$ and GJIC in oral cancer cells (101). Contradictory results have been observed in other cell types such as p19 embryonic carcinoma cells, human pluripotent teratocarcinoma cells and cutaneous squamous cell carcinoma SCC-13 cells (102-104). This was hypothesized to be due to variation in tissue-specific transcriptional regulators and connexin expression distribution, leading to opposing cellular mechanics and outcomes (101). The exact underlying mechanism remains unknown and will require further studies before the development of novel treatment options.

Docetaxel is the first cytotoxic drug reported to demonstrate benefits in the treatment for advanced hormone refractory prostate cancer (105). However, resistance against docetaxel has always been a challenge, and is found in more than $50 \%$ of patients receiving this drug as first-line therapy (106). Extensive efforts have focused on improving the responsiveness and overcoming resistance in metastatic prostate cancer (107). Cx43 expression has shown promising potential in its application as an adjunct agent to docetaxel. In PC-3 cells, Cx43 expression downregulated Bcl-2 expression, and apoptosis is associated with significantly increased sensitivity to docetaxel both in vitro and in vivo, and addition of non-viral Cx43 gene therapy to conventional docetaxel treatment caused a significant increment in the tumour xenograft suppression effect (108). Taxels have differential cytotoxicities that are dependent upon the presence of functional gap junctions (109). The distribution and combination of gap junctions may therefore need to be taken into consideration when using taxols in different types of cancers. In another study, forced Cx43 expression enhanced prostate cancer cell sensitivity to TNF $\alpha$ (110). The presence of $\mathrm{Cx} 26$, another commonly investigated connexin, has been associated with tumour prognosis, oncogene expression, recurrence and higher tumour grade $(111,112)$. Cx26 may therefore be a good candidate for prediction of prognosis and recurrence (111). Cx26 may also be involved in tumour suppression. It was demonstrated that Cx26 expression suppressed the growth of HeLa cells in vivo and in vitro, with insignificant changes in GJIC (113). Organic selenium compounds are $\mathrm{Cx} 26$ transcriptional upregulators, and have been evaluated in clinical trials for adenomatous polyp recurrence (114).

Suicide gene therapy has become an area of intense investigation in the treatment of different cancers (115). Suicide genes are defined as those with protein products, when expressed, are non-toxic to cells, but are converted into toxic metabolites upon exposure to a pro-drug. However, various suicide gene products may induce a bystander effect (Fig. 3). This describes a situation where a toxic effect, such as cell death, propagates from nongene-modified tumour cells to neighbouring cells. This is dependent on the function of gap junctions, and can be exploited for therapeutic use. For example, the bystander effect can be enhanced by treating cancer cells with both Cx43 and human herpes simplex virus thymidine kinase type (HSV-TK) transfection, leading to cell death $(116,117)$. Similar effects were noted following the replacement of Cx32 with Cx43 (118). By utilizing the bystander effect it may be possible to amplify the cytotoxicity of certain cell type-specific

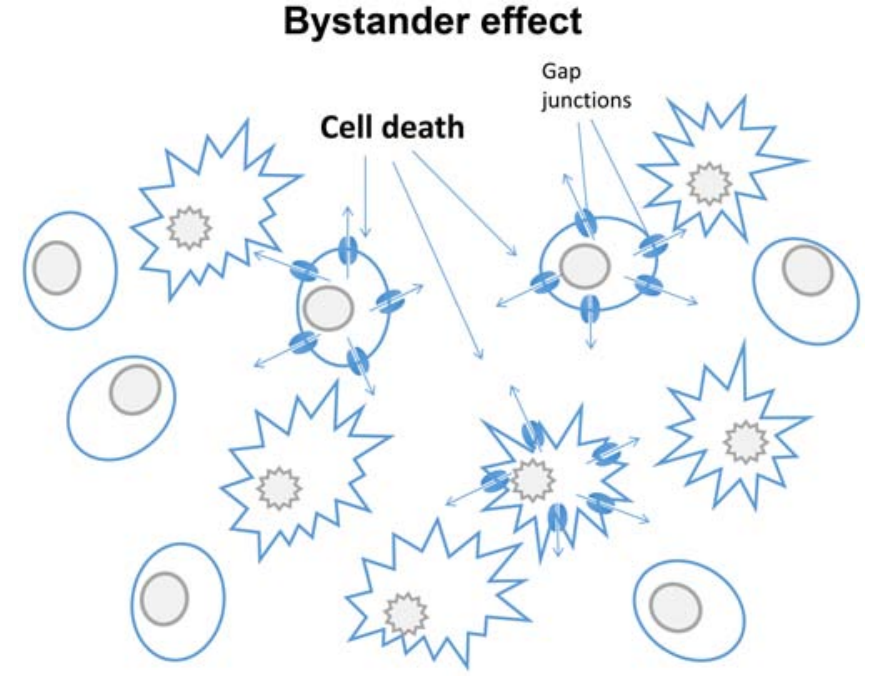

Figure 3. The bystander effect. Cell death can be propagated from affected cells to neighboring cells via gap junctions. Reproduced from Wong et al (153) with permission.

drugs (119). The effect was however limited to cancer cells that were able to utilize and assemble the induced connexins into functional gap junctions (120). When treating prostate cancer, tumour cell responsiveness was significantly enhanced when Cx26 was applied. This bystander effect can also be utilized in therapies using ionizing radiation. Radiation traversed the cell nucleus to induce response or damage in neighboring cells, and nearby non-irradiated cells showed characteristics of damages and responses induced by irradiation. It was then confirmed that $\mathrm{Cx} 43$ mediated GJIC that transmited radiation stress from the irradiated cells to the bystander cells (121). This opens up an opportunity for improving therapy to enhance the efficacy of not only chemotherapy, but also radiotherapy in cancer treatment. There are also other limitations to the clinical application, such as the fact that the lipophilicity may be too low to cross the blood-brain barrier and the need to use systemically dangerous dosages that can produce side effects such as cardiac conduction slowing (122), which can precipitate lethal arrhythmias $(118,123,124)$.

\section{Conclusion}

Gap junction proteins are ubiquitously expressed with some tissue-specific subtypes. Their expression patterns in different diseases are now better characterized. Attempts have been made to examine the consequences of influencing gap junctions by direct modulators or antisense technology, with many successes in pre-clinical disease models. The ability of gap junction proteins to regulate immune responses, cell proliferation, migration, apoptosis and carcinogenesis makes them attractive therapeutic targets to halt the progression of inflammatory and neoplastic disorders. It may be worthwhile to elucidate the gap junction protein pathways to identify more accurate prognostic biomarkers (125). The use of pre-clinical models will continue to provide a platform on which these investigations are conducted (126-139), and for the development of novel therapeutic agents for future clinical applications in these disorders (136,140-152). 


\section{Acknowledgements}

Dr Gary Tse received a BBSRC Doctoral Training Award at the University of Cambridge and is grateful to the Croucher Foundation for its support of his non-clinical and clinical assistant professorships. Dr Yin Wah Fiona Chan was supported by the ESRC for her research at the University of Cambridge.

\section{References}

1. Kanno $\mathrm{Y}$ and Loewenstein WR: Low-resistance coupling between gland cells. Some observations on intercellular contact membranes and intercellular space. Nature 201: 194-195, 1964.

2. Lawrence TS, Beers WH and Gilula NB: Transmission of hormonal stimulation by cell-to-cell communication. Nature 272 : 501-506, 1978

3. Zhou JZ and Jiang JX: Gap junction and hemichannel-independent actions of connexins on cell and tissue functions - an update. FEBS Lett 588: 1186-1192, 2014.

4. Tse G and Yan BP: Electrophysiological mechanisms of long and short QT syndromes: Insights from mouse models. Int J Cardiol Heart Vasc (In press).

5. Veeraraghavan R, Lin J, Hoeker GS, Keener JP, Gourdie RG and Poelzing S: Sodium channels in the $\mathrm{Cx} 43$ gap junction perinexus may constitute a cardiac ephapse: An experimental and modeling study. Pflugers Arch 467: 2093-2105, 2015.

6. Veeraraghavan R, Gourdie RG and Poelzing S: Mechanisms of cardiac conduction: A history of revisions. Am J Physiol Heart Circ Physiol 306: H619-H627, 2014.

7. Koval M, Isakson BE and Gourdie RG: Connexins, pannexins and innexins: Protein cousins with overlapping functions. FEBS Lett 588: 1185, 2014.

8. Tse G: Bothtransmuraldispersion of repolarization and transmural dispersion of refractoriness are poor predictors of arrhythmogenicity: A role for the index of Cardiac Electrophysiological Balance (QT/QRS)? J Geriatr Cardiol (In press).

9. Harris AL: Emerging issues of connexin channels: Biophysics fills the gap. Q Rev Biophys 34: 325-472, 2001.

10. Söhl G and Willecke K: Gap junctions and the connexin protein family. Cardiovasc Res 62: 228-232, 2004.

11. Ke Q, Li L, Cai B, Liu C, Yang Y, Gao Y, Huang W, Yuan X, Wang T, Zhang Q, et al: Connexin 43 is involved in the generation of human-induced pluripotent stem cells. Hum Mol Genet 22: 2221-2233, 2013

12. Becker DL, Thrasivoulou $C$ and Phillips AR: Connexins in wound healing; perspectives in diabetic patients. Biochim Biophys Acta 1818: 2068-2075, 2012.

13. Crespo Yanguas S, Willebrords J, Maes M, da Silva TC, Veloso Alves Pereira I, Cogliati B, Zaidan Dagli ML and Vinken M: Connexins and pannexins in liver damage. EXCLI J 15: 177-186, 2016.

14. Tse G and Yeo JM: Conduction abnormalities and ventricular arrhythmogenesis: The roles of sodium channels and gap junctions. Int J Cardiol Heart Vasc 9: 75-82, 2015.

15. Goldberg GS, Valiunas V and Brink PR: Selective permeability of gap junction channels. Biochim Biophys Acta 1662: 96-101, 2004.

16. Wilgenbus KK, Kirkpatrick CJ, Knuechel R, Willecke K and Traub O: Expression of Cx26, Cx32 and $\mathrm{Cx} 43$ gap junction proteins in normal and neoplastic human tissues. Int J Cancer 51: 522-529, 1992

17. Bukauskas FF and Verselis VK: Gap junction channel gating. Biochim Biophys Acta 1662: 42-60, 2004.

18. Bao L, Sachs F and Dahl G: Connexins are mechanosensitive. Am J Physiol Cell Physiol 287: C1389-C1395, 2004.

19. Tse G, Yeo JM, Tse V, Kwan J and Sun B: Gap junction inhibition by heptanol increases ventricular arrhythmogenicity by reducing conduction velocity without affecting repolarization properties or myocardial refractoriness in Langendorff-perfused mouse hearts. Mol Med Rep 14: 4069-4074, 2016.

20. Musil LS and Goodenough DA: Biochemical analysis of connexin43 intracellular transport, phosphorylation, and assembly into gap junctional plaques. J Cell Biol 115: 1357-1374, 1991.

21. Bennett MV and Verselis VK: Biophysics of gap junctions Semin Cell Biol 3: 29-47, 1992.
22. Meyer RA, Lampe PD, Malewicz B, Baumann WJ and Johnson RG: Enhanced gap junction formation with LDL and apolipoprotein B. Exp Cell Res 196: 72-81, 1991.

23. Meyer R, Malewicz B, Baumann WJ and Johnson RG: Increased gap junction assembly between cultured cells upon cholesterol supplementation. J Cell Sci 96: 231-238, 1990.

24. O'Carroll SJ, Becker DL, Davidson JO, Gunn AJ, Nicholson LF and Green CR: The use of connexin-based therapeutic approaches to target inflammatory diseases. Methods Mol Biol 1037: 519-546, 2013.

25. Beyer EC and Berthoud VM: Gap junction synthesis and degradation as therapeutic targets. Curr Drug Targets 3: 409-416, 2002.

26. Plum A, Hallas G, Magin T, Dombrowski F, Hagendorff A, Schumacher B, Wolpert C, Kim J, Lamers WH, Evert M, et al: Unique and shared functions of different connexins in mice. Curr Biol 10: 1083-1091, 2000.

27. Scott CA, Tattersall D, O'Toole EA and Kelsell DP: Connexins in epidermal homeostasis and skin disease. Biochim Biophys Acta 1818: 1952-1961, 2012

28. Richard G: Connexin disorders of the skin. Clin Dermatol 23: 23-32, 2005.

29. Labarthe MP, Bosco D, Saurat JH, Meda P and Salomon D: Upregulation of connexin 26 between keratinocytes of psoriatic lesions. J Invest Dermatol 111: 72-76, 1998.

30. Lucke T, Choudhry R, Thom R, Selmer IS, Burden AD and Hodgins MB: Upregulation of connexin 26 is a feature of keratinocyte differentiation in hyperproliferative epidermis, vaginal epithelium, and buccal epithelium. J Invest Dermatol 112: 354-361, 1999.

31. Djalilian AR, McGaughey D, Patel S, Seo EY, Yang C, Cheng J, Tomic M, Sinha S, Ishida-Yamamoto A and Segre JA:Connexin 26 regulates epidermal barrier and wound remodeling and promotes psoriasiform response. J Clin Invest 116: 1243-1253, 2006.

32. Iossa S, Marciano E and Franzé A: GJB2 gene mutations in syndromic skin diseases with sensorineural hearing loss. Curr Genomics 12: 475-785, 2011.

33. Levit NA and White TW: Connexin hemichannels influence genetically determined inflammatory and hyperproliferative skin diseases. Pharmacol Res 99: 337-343, 2015.

34. Masgrau-Peya E, Salomon D, Saurat JH and Meda P: In vivo modulation of connexins 43 and 26 of human epidermis by topical retinoic acid treatment. J Histochem Cytochem 45: $1207-1215,1997$.

35. Kanady JD, Dellinger MT, Munger SJ, Witte MH and Simon AM: Connexin37 and Connexin43 deficiencies in mice disrupt lymphatic valve development and result in lymphatic disorders including lymphedema and chylothorax. Dev Biol 354: 253-266, 2011.

36. Meens MJ, Sabine A, Petrova TV and Kwak BR: Connexins in lymphatic vessel physiology and disease. FEBS Lett 588: 1271-1277, 2014

37. Wick N, Saharinen P, Saharinen J, Gurnhofer E, Steiner CW, Raab I, Stokic D, Giovanoli P, Buchsbaum S, Burchard A, et al: Transcriptomal comparison of human dermal lymphatic endothelial cells ex vivo and in vitro. Physiol Genomics 28: 179-192, 2007.

38. Finegold DN, Schacht V, Kimak MA, Lawrence EC, Foeldi E, Karlsson JM, Baty CJ and Ferrell RE: HGF and MET mutations in primary and secondary lymphedema. Lymphat Res Biol 6: 65-68, 2008.

39. Finegold DN, Baty CJ, Knickelbein KZ, Perschke S, Noon SE, Campbell D, Karlsson JM, Huang D, Kimak MA, Lawrence EC, et al: Connexin 47 mutations increase risk for secondary lymphedema following breast cancer treatment. Clin Cancer Res 18: 2382-2390, 2012.

40. Losa D and Chanson M: The lung communication network. Cell Mol Life Sci 72: 2793-2808, 2015.

41. Freund-Michel V, Muller B, Marthan R, Savineau JP and Guibert C: Expression and role of connexin-based gap junctions in pulmonary inflammatory diseases. Pharmacol Ther 164: 105-119, 2016.

42. Okamoto T, Akiyama M, Takeda M, Gabazza EC, Hayashi T and Suzuki K: Connexin32 is expressed in vascular endothelial cells and participates in gap-junction intercellular communication. Biochem Biophys Res Commun 382: 264-268, 2009.

43. Ram A, Singh SK, Singh VP, Kumar S and Ghosh B: Inhaled carbenoxolone prevents allergic airway inflammation and airway hyperreactivity in a mouse model of asthma. Int Arch Allergy Immunol 149: 38-46, 2009. 
44. Tamaya T, Sato S and Okada HH: Possible mechanism of steroid action of the plant herb extracts glycyrrhizin, glycyrrhetinic acid, and paeoniflorin: Inhibition by plant herb extracts of steroid protein binding in the rabbit. Am J Obstet Gynecol 155: 1134-1139, 1986.

45. Park SJ, Lee KS, Kim SR, Min KH, Lee KY, Choe YH, Park SY, Hong SH and Lee YC: Change of connexin 37 in allergen-induced airway inflammation. Exp Mol Med 39: 629-640, 2007.

46. Koval M, Billaud M, Straub AC, Johnstone SR, Zarbock A, Duling BR and Isakson BE: Spontaneous lung dysfunction and fibrosis in mice lacking connexin 40 and endothelial cell connexin 43. Am J Pathol 178: 2536-2546, 2011.

47. Kim J, Hwangbo C, Hu X, Kang Y, Papangeli I, Mehrotra D, Park H, Ju H, McLean DL, Comhair SA, et al: Restoration of impaired endothelial myocyte enhancer factor 2 function rescues pulmonary arterial hypertension. Circulation 131: 190-199, 2015

48. Zhang J, Wang W, Sun J, Li Q, Liu J, Zhu H, Chen T, Wang H, Yu S, Sun G, et al: Gap junction channel modulates pulmonary vascular permeability through calcium in acute lung injury: An experimental study. Respiration 80: 236-245, 2010.

49. Chadjichristos CE, Scheckenbach KE, van Veen TA, Richani Sarieddine MZ, de Wit C, Yang Z, Roth I, Bacchetta M, Viswambharan H, Foglia B, et al: Endothelial-specific deletion of connexin40 promotes atherosclerosis by increasing CD73-dependent leukocyte adhesion. Circulation 121: 123-131, 2010.

50. Rignault S, Haefliger JA, Waeber B, Liaudet L and Feihl F: Acute inflammation decreases the expression of connexin 40 in mouse lung. Shock 28: 78-85, 2007.

51. O'Donnell JJ III, Birukova AA, Beyer EC and Birukov KG: Gap junction protein connexin43 exacerbates lung vascular permeability. PLoS One 9: e100931, 2014

52. Kasper M, Traub O, Reimann T, Bjermer L, Grossmann H, Müller $\mathrm{M}$ and Wenzel $\mathrm{KW}$ : Upregulation of gap junction protein connexin43 in alveolar epithelial cells of rats with radiation-induced pulmonary fibrosis. Histochem Cell Biol 106: 419-424, 1996

53. Fernandez-Cobo M, Gingalewski C and De Maio A: Expression of the connexin 43 gene is increased in the kidneys and the lungs of rats injected with bacterial lipopolysaccharide. Shock 10 : 97-102, 1998.

54. Zhang J, Yang GM, Zhu Y, Peng XY, Li T and Liu LM: Role of connexin 43 in vascular hyperpermeability and relationship to Rock1-MLC20 pathway in septic rats. Am J Physiol Lung Cell Mol Physiol 309: L1323-L1332, 2015.

55. Molina SA, Stauffer B, Moriarty HK, Kim AH, McCarty NA and Koval M: Junctional abnormalities in human airway epithelial cells expressing F508del CFTR. Am J Physiol Lung Cell Mol Physiol 309: L475-L487, 2015.

56. Trovato-Salinaro A, Trovato-Salinaro E, Failla M, Mastruzzo C, Tomaselli V, Gili E, Crimi N, Condorelli DF and Vancheri C: Altered intercellular communication in lung fibroblast cultures from patients with idiopathic pulmonary fibrosis. Respir Res 7: $122,2006$.

57. Montani D, Günther S, Dorfmüller P, Perros F, Girerd B, Garcia G, Jaïs X, Savale L, Artaud-Macari E, Price LC, et al: Pulmonary arterial hypertension. Orphanet J Rare Dis 8: 97, 2013.

58. Yen CH,Leu S, Lin YC, Kao YH, Chang LT, Chua S, Fu M, Wu CJ, Sun CK and Yip HK: Sildenafil limits monocrotaline-induced pulmonary hypertension in rats through suppression of pulmonary vascular remodeling. J Cardiovasc Pharmacol 55: 574-584, 2010.

59. Gairhe S, Bauer NN, Gebb SA and McMurtry IF: Myoendothelial gap junctional signaling induces differentiation of pulmonary arterial smooth muscle cells. Am J Physiol Lung Cell Mol Physiol 301: L527-L535, 2011.

60. Segretain D and Falk MM: Regulation of connexin biosynthesis, assembly, gap junction formation, and removal. Biochim Biophys Acta 1662: 3-21, 2004.

61. Patel SJ, King KR, Casali M and Yarmush ML: DNA-triggered innate immune responses are propagated by gap junction communication. Proc Natl Acad Sci USA 106: 12867-12872, 2009.

62. Naiki-Ito A, Asamoto M, Naiki T, Ogawa K, Takahashi S, Sato $\mathrm{S}$ and Shirai T: Gap junction dysfunction reduces acetaminophen hepatotoxicity with impact on apoptotic signaling and connexin 43 protein induction in rat. Toxicol Pathol 38: 280-286, 2010
63. Asamoto M,Hokaiwado N, Murasaki T and Shirai T: Connexin 32 dominant-negative mutant transgenic rats are resistant to hepatic damage by chemicals. Hepatology 40: 205-210, 2004.

64. Hokaiwado N, Asamoto M, Futakuchi M, Ogawa K, Takahashi S and Shirai T: Both early and late stages of hepatocarcinogenesis are enhanced in $\mathrm{Cx} 32$ dominant negative mutant transgenic rats with disrupted gap junctional intercellular communication. J Membr Biol 218: 101-106, 2007.

65. Maes M, McGill MR, da Silva TC, Abels C, Lebofsky M, Maria Monteiro de Araújo C, Tiburcio T, Veloso Alves Pereira I, Willebrords J, Crespo Yanguas S, et al: Involvement of connexin43 in acetaminophen-induced liver injury. Biochim Biophys Acta 1862: 1111-1121, 2016.

66. Balasubramaniyan V, Dhar DK, Warner AE, Vivien Li WY, Amiri AF, Bright B, Mookerjee RP, Davies NA, Becker DL and Jalan R: Importance of connexin-43 based gap junction in cirrhosis and acute-on-chronic liver failure. J Hepatol 58: 1194-1200, 2013

67. Gotthardt D, Riediger C, Weiss KH, Encke J, Schemmer P, Schmidt J and Sauer P: Fulminant hepatic failure: etiology and indications for liver transplantation. Nephrol Dial Transplant 22 (Suppl 8): viii5-viiii, 2007.

68. Maes M, McGill MR, da Silva TC, Lebofsky M, Maria Monteiro de Araújo C, Tiburcio T, Veloso Alves Pereira I, Willebrords J, Crespo Yanguas S, Farhood A, et al: Connexin32: A mediator of acetaminophen-induced liver injury? Toxicol Mech Methods 26: 88-96, 2016.

69. Igarashi I, Maejima T, Kai K, Arakawa S, Teranishi M and Sanbuissho A: Role of connexin 32 in acetaminophen toxicity in a knockout mice model. Exp Toxicol Pathol 66: 103-110, 2014.

70. Du K, Williams CD, McGill MR, Xie Y, Farhood A, Vinken $M$ and Jaeschke $H$ : The gap junction inhibitor 2-aminoethoxy-diphenyl-borate protects against acetaminophen hepatotoxicity by inhibiting cytochrome P450 enzymes and c-jun N-terminal kinase activation. Toxicol Appl Pharmacol 273: 484-491, 2013

71. Patel SJ, Milwid JM, King KR, Bohr S, Iracheta-Vellve A, Li M, Vitalo A, Parekkadan B, Jindal R and Yarmush ML: Gap junction inhibition prevents drug-induced liver toxicity and fulminant hepatic failure. Nat Biotechnol 30: 179-183, 2012.

72. Ogawa K, Pitchakarn P, Suzuki S, Chewonarin T, Tang M, Takahashi S, Naiki-Ito A, Sato S, Takahashi S, Asamoto M, et al: Silencing of connexin 43 suppresses invasion, migration and lung metastasis of rat hepatocellular carcinoma cells. Cancer Sci 103: 860-867, 2012

73. Zhang D, Kaneda M, Nakahama K, Arii S and Morita I: Connexin 43 expression promotes malignancy of $\mathrm{HuH} 7$ hepatocellular carcinoma cells via the inhibition of cell-cell communication. Cancer Lett 252: 208-215, 2007.

74. Ionta M, Ferreira RA, Pfister SC and Machado-Santelli GM: Exogenous $\mathrm{Cx} 43$ expression decrease cell proliferation rate in rat hepatocarcinoma cells independently of functional gap junction. Cancer Cell Int 9: 22, 2009.

75. Igarashi I, Makino T, Suzuki Y, Kai K, Teranishi M, Takasaki W and Furuhama K: Background lesions during a 24-month observation period in connexin 32-deficient mice. J Vet Med Sci 75: 207-210, 2013

76. Loch-Caruso R, Galvez MM, Brant K and Chung D: Cell and toxicant specific phosphorylation of conexin43: Effects of lindane and TPA on rat myometrial and WB-F344 liver cell gap junctions. Cell Biol Toxicol 20: 147-169, 2004.

77. Mograbi B, Corcelle E, Defamie N, Samson M, Nebout M, Segretain D, Fénichel P and Pointis G: Aberrant connexin 43 endocytosis by the carcinogen lindane involves activation of the ERK/mitogen-activated protein kinase pathway. Carcinogenesis 24: 1415-1423, 2003.

78. Caruso RL, Upham BL, Harris C and Trosko JE: Biphasic lindane-induced oxidation of glutathione and inhibition of gap junctions in myometrial cells. Toxicol Sci 86: 417-426, 2005.

79. Defamie N, Mograbi B, Roger C, Cronier L, Malassine A, Brucker-Davis F, Fenichel P, Segretain D and Pointis G: Disruption of gap junctional intercellular communication by lindane is associated with aberrant localization of connexin 43 and zonula occludens-1 in 42GPA9 Sertoli cells. Carcinogenesis 22: $1537-1542,2001$

80. Weigelt B, Peterse JL and van't Veer LJ: Breast cancer metastasis: Markers and models. Nat Rev Cancer 5: 591-602, 2005.

81. Plante I, Stewart MK, Barr K, Allan AL and Laird DW: Cx43 suppresses mammary tumor metastasis to the lung in a $\mathrm{Cx} 43$ mutant mouse model of human disease. Oncogene 30: 1681-1692, 2011. 
82. Sirnes S, Bruun J, Kolberg M,Kjenseth A, Lind GE, Svindland A, Brech A, Nesbakken A, Lothe RA, Leithe E, et al: Connexin43 acts as a colorectal cancer tumor suppressor and predicts disease outcome. Int J Cancer 131: 570-581, 2012.

83. Bernzweig J, Heiniger B, Prasain K, Lu J, Hua DH and Nguyen TA: Anti-breast cancer agents, quinolines, targeting gap junction. Med Chem 7: 448-453, 2011.

84.Liu CL, Huang YS, Hosokawa M, Miyashita K and Hu ML: Inhibition of proliferation of a hepatoma cell line by fucoxanthin in relation to cell cycle arrest and enhanced gap junctional intercellular communication. Chem Biol Interact 182: 165-172, 2009.

85. Soobrattee MA, Bahorun T and Aruoma OI: Chemopreventive actions of polyphenolic compounds in cancer. Biofactors 27 19-35, 2006.

86. Wang L, Zeng Y, Liu Y, Hu X, Li S, Wang Y, Li L, Lei Z and Zhang Z: Fucoxanthin induces growth arrest and apoptosis in human bladder cancer T24 cells by up-regulation of p21 and down-regulation of mortalin. Acta Biochim Biophys Sin (Shanghai) 46: 877-884, 2014

87. Marchenko ND, Zaika A and Moll UM: Death signal-induced localization of p53 protein to mitochondria. A potential role in apoptotic signaling. J Biol Chem 275: 16202-16212, 2000.

88. Januar HI, Dewi AS, Marraskuranto E and Wikanta T: In silico study of fucoxanthin as a tumor cytotoxic agent. J Pharm Bioallied Sci 4: 56-59, 2012.

89. Nakamura Y, Chang CC, Mori T, Sato K, Ohtsuki K, Upham BL and Trosko JE: Augmentation of differentiation and gap junction function by kaempferol in partially differentiated colon cancer cells. Carcinogenesis 26: 665-671, 2005.

90.Ding Y and Nguyen TA: Gap junction enhancer potentiates cytotoxicity of cisplatin in breast cancer cells. J Cancer Sci Ther 4: 371-378, 2012.

91. Sáez CG, Velásquez L, Montoya M, Eugenín E and Alvarez MG: Increased gap junctional intercellular communication is directly related to the anti-tumor effect of all-trans-retinoic acid plus tamoxifen in a human mammary cancer cell line. J Cell Biochem 89: 450-461, 2003

92. Wernyj RP and Morin PJ: Molecular mechanisms of platinum resistance: Still searching for the Achilles' heel. Drug Resist Updat 7: 227-232, 2004.

93.Peterson-Roth E, Brdlik CM and Glazer PM: Src-Induced cisplatin resistance mediated by cell-to-cell communication. Cancer Res 69: 3619-3624, 2009.

94. Isakov N, Bleackley RC, Shaw J and Altman A: Teleocidin and phorbol ester tumor promoters exert similar mitogenic effects on human lymphocytes. Biochem Biophys Res Commun 130: 724-731, 1985

95.Procopio A, Gismondi A, Paolini R, Morrone S, Testi R, Piccoli M, Frati L, Herberman RB and Santoni A: Proliferative effects of 12-O-tetradecanoylphorbol-13-acetate (TPA) and calcium ionophores on human large granular lymphocytes (LGL). Cell Immunol 113: 70-81, 1988.

96. Bigelow K and Nguyen TA: Increase of gap junction activities in SW480 human colorectal cancer cells. BMC Cancer 14: 502, 2014.

97.Leithe E and Rivedal E: Ubiquitination and down-regulation of gap junction protein connexin-43 in response to 12-O-tetradecanoylphorbol 13-acetate treatment. J Biol Chem 279: 50089-50096, 2004

98. Solomon VR and Lee H: Quinoline as a privileged scaffold in cancer drug discovery. Curr Med Chem 18: 1488-1508, 2011.

99.Lim YC, Kang HJ, Kim YS and Choi EC: All-trans-retinoic acid inhibits growth of head and neck cancer stem cells by suppression of Wnt $/ \beta$-catenin pathway. Eur J Cancer 48 3310-3318, 2012

100. Ara C, Massimi M and Devirgiliis Conti L: Retinoic acid modulates gap junctional intercellular communication in hepatocytes and hepatoma cells. Cell Mol Life Sci 59: 1758-1765, 2002

101. Wang J, Dai Y, Huang Y, Chen X, Wang H, Hong Y, Xia J and Cheng B: All-trans retinoic acid restores gap junctional intercellular communication between oral cancer cells with upregulation of $\mathrm{Cx} 32$ and $\mathrm{Cx} 43$ expressions in vitro. Med Oral Patol Oral Cir Bucal 18: e569-e577, 2013.

102. Belliveau DJ, Bechberger JF, Rogers KA and Naus CC: Differential expression of gap junctions in neurons and astrocytes derived from P19 embryonal carcinoma cells. Dev Genet 21: 187-200, 1997

103. Bani-Yaghoub M, Bechberger JF and Naus CC: Reduction of connexin43 expression and dye-coupling during neuronal differentiation of human NTera2/clone D1 cells. J Neurosci Res 49: 19-31, 1997.
104. Rudkin GH, Carlsen BT, Chung CY, Huang W, Ishida K, Anvar B, Yamaguchi DT and Miller TA: Retinoids inhibit squamous cell carcinoma growth and intercellular communication. J Surg Res 103: 183-189, 2002.

105. Picus J and Schultz M: Docetaxel (Taxotere) as monotherapy in the treatment of hormone-refractory prostate cancer: Preliminary results. Semin Oncol 26 (Suppl 17): 14-18, 1999.

106. Petrylak DP, Tangen CM, Hussain MH, Lara PN Jr, Jones JA, Taplin ME, Burch PA, Berry D, Moinpour C, Kohli M, et al: Docetaxel and estramustine compared with mitoxantrone and prednisone for advanced refractory prostate cancer. N Engl J Med 351: 1513-1520, 2004

107. Hwang C: Overcoming docetaxel resistance in prostate cancer: A perspective review. Ther Adv Med Oncol 4: 329-340, 2012.

108. Fukushima M, Hattori Y, Yoshizawa T and Maitani Y: Combination of non-viral connexin 43 gene therapy and docetaxel inhibits the growth of human prostate cancer in mice. Int J Oncol 30: 225-231, 2007.

109. Tang N, Wang Q, Wu D, Zhang S, Zhang Y and Tao L: Differential effects of paclitaxel and docetaxel on gap junctions affects their cytotoxicities in transfected HeLa cells. Mol Med Rep 8: 638-644, 2013

110. Wang M, Berthoud VM and Beyer EC: Connexin43 increases the sensitivity of prostate cancer cells to TNFalpha-induced apoptosis. J Cell Sci 120: 320-329, 2007.

111. Nomura S, Maeda K, Noda E, Inoue T, Fukunaga S, Nagahara H and Hirakawa K: Clinical significance of the expression of connexin26 in colorectal cancer. J Exp Clin Cancer Res 29: 79, 2010.

112. Knösel T, Emde A, Schlüns K, Chen Y, Jürchott K, Krause M, Dietel $\mathrm{M}$ and Petersen I: Immunoprofiles of 11 biomarkers using tissue microarrays identify prognostic subgroups in colorectal cancer. Neoplasia 7: 741-747, 2005.

113. Mesnil M, Krutovskikh V, Piccoli C, Elfgang C, Traub O, Willecke $\mathrm{K}$ and Yamasaki $\mathrm{H}$ : Negative growth control of HeLa cells by connexin genes: Connexin species specificity. Cancer Res 55: 629-639, 1995.

114. Goulet AC, Watts G, Lord JL and Nelson MA: Profiling of selenomethionine responsive genes in colon cancer by microarray analysis. Cancer Biol Ther 6: 494-503, 2007.

115. Dilber MS and Gahrton G: Suicide gene therapy: Possible applications in haematopoietic disorders. J Intern Med 249: 359-367, 2001.

116. Mesnil M, Piccoli C, Tiraby G, Willecke K and Yamasaki H: Bystander killing of cancer cells by herpes simplex virus thymidine kinase gene is mediated by connexins. Proc Natl Acad Sci USA 93: 1831-1835, 1996.

117. Boucher PD, Ruch RJ and Shewach DS: Differential ganciclovir-mediated cytotoxicity and bystander killing in human colon carcinoma cell lines expressing herpes simplex virus thymidine kinase. Hum Gene Ther 9: 801-814, 1998.

118. Grek CL, Rhett JM and Ghatnekar GS: Cardiac to cancer: Connecting connexins to clinical opportunity. FEBS Lett 588: 1349-1364, 2014.

119. Tanaka T, Yamasaki H and Mesnil M: Induction of a bystander effect in HeLa cells by using a bigenic vector carrying viral thymidine kinase and connexin32 genes. Mol Carcinog 30: 176-180, 2001

120. Mesnil M and Yamasaki H: Bystander effect in herpes simplex virus-thymidine kinase/ganciclovir cancer gene therapy: Role of gap-junctional intercellular communication. Cancer Res 60: 3989-3999, 2000

121. Azzam EI, de Toledo SM and Little JB: Direct evidence for the participation of gap junction-mediated intercellular communication in the transmission of damage signals from alpha -particle irradiated to nonirradiated cells. Proc Natl Acad Sci USA 98: 473-478, 2001.

122. Eloff BC, Lerner DL, Yamada KA, Schuessler RB, Saffitz JE and Rosenbaum DS: High resolution optical mapping reveals conduction slowing in connexin43 deficient mice. Cardiovasc Res 51: 681-690, 2001.

123. Tse G: Mechanisms of cardiac arrhythmias. J Arrhythm 32: $75-81,2016$

124. Tse G, Wong ST, Tse V, Lee YT, Lin HY and Yeo JM: Cardiac dynamics: Alternans and arrhythmogenesis. J Arrhythm 32: 411-417, 2016

125. Schalper KA, Carvajal-Hausdorf D and Oyarzo MP: Possible role of hemichannels in cancer. Front Physiol 5: 237, 2014.

126. Tse G, Wong ST, Tse V and Yeo JM: Depolarization vs. repolarization: What is the mechanism of ventricular arrhythmogenesis underlying sodium channel haploinsufficiency in mouse hearts? Acta Physiol (Oxf) 218: 234-235, 2016. 
127.Tse G: (Tpeak-Tend)/QRS and (Tpeak-Tend)/(QT x QRS): Novel markers for predicting arrhythmic risk in the Brugada syndrome. Europace: Oct 5, 2016 (Epub ahead of print).

128. Tse G, Wong ST, Tse V and Yeo JM: Determination of action potential wavelength restitution in Scn5a/- mouse hearts modelling human Brugada syndrome. J Physiol (In press).

129. Tse G: Novel conduction repolarization indices for the stratification of arrhythmic risk. J Geriatr Cardiol 13: 811-812, 2016.

130.Tse G, Wong ST, Tse V and Yeo JM: Variability in local action potential durations, dispersion of repolarization and wavelength restitution in aged wild type and $\mathrm{Scn} 5 \mathrm{a} /$ - mouse hearts modelling human Brugada syndrome. J Geriatr Cardiol (In press).

131. Hu Z, Chen Z, Wang Y, et al: Effects of granulocyte colony-stimulating factor on rabbit carotid and swine heart models of chronic obliterative arterial disease. Mol Med Rep (In press).

132. Tse G, Tse V and Yeo JM: Ventricular anti-arrhythmic effects of heptanol in hypokalaemic, Langendorff-perfused mouse hearts. Biomed Rep 4: 313-324, 2016.

133. Tse G, Tse V, Yeo JM and Sun B: Atrial anti-arrhythmic effects of heptanol in Langendorff-perfused mouse hearts. PLoS One 11: e0148858, 2016

134. Tse G, Wong ST, Tse V and Yeo JM: Restitution analysis of alternans using dynamic pacing and its comparison with S1S2 restitution in heptanol-treated, hypokalaemic Langendorff-perfused mouse hearts. Biomed Rep 4: 673-680, 2016

135. Tse G, Wong ST, Tse V and Yeo JM: Monophasic action potential recordings: Which is the recording electrode? J Basic Clin Physiol Pharmacol 27: 457-462, 2016

136. Tse G, Lai ET, Yeo JM, Tse V and Wong SH: Mechanisms of electrical activation and conduction in the gastrointestinal system: Lessons from cardiac electrophysiology. Front Physiol 7: $182,2016$.

137. Tse G, Lai ET, Tse V and Yeo JM: Molecular and electrophysiological mechanisms underlying cardiac arrhythmogenesis in diabetes mellitus. J Diabetes Res 2016: 2848759, 2016.

138. Tse G, Lai ET, Yeo JM and Yan BP: Electrophysiological mechanisms of Bayés syndrome: Insights from clinical and mouse studies. Front Physiol 7: 188, 2016.

139. Tse G, Sun B, Wong ST, Tse V and Yeo JM: Anti-arrhythmic effects of hypercalcaemia treatment in hyperkalaemic, Langendorff-perfused mouse hearts. Biomed Rep 5: 301-310, 2016

140. Chen Z, Sun B, Tse G, Jiang J and Xu W: Reversibility of both sinus node dysfunction and reduced HCN4 mRNA expression level in an atrial tachycardia pacing model of tachycardia-bradycardia syndrome in rabbit hearts. Int J Clin Exp Pathol 9: 8526-8531, 2016

141. Tse G, Yeo JM, Chan YW, Lai ET and Yan BP: What is the arrhythmic substrate in viral myocarditis? Insights from clinical and animal studies. Front Physiol 7: 308, 2016.

142. Choy L, Yeo JM, Tse V, Chan SP and Tse G: Cardiac disease and arrhythmogenesis: Mechanistic insights from mouse models. Int J Cardiol Heart Vasc 12: 1-10, 2016.
143. Tse G and Yan BP: Novel arrhythmic risk markers incorporating QRS dispersion: QRSd x (Tpeak - Tend )/QRS and QRSd x (Tpeak - Tend )/(QT x QRS). Ann Noninvasive Electrocardiol: Aug 18, 2016 (Epub ahead of print).

144. Tse G,Lai ET,Lee AP, Yan BP and Wong SH:Electrophysiological mechanisms of gastrointestinal arrhythmogenesis: Lessons from the heart. Front Physiol 7: 230, 2016.

145. Tse G and Yan BP: Traditional and novel electrocardiographic conduction and repolarization markers of sudden cardiac death. Europace: Oct 4, 2016 (Epub ahead of print).

146. Tse G, Yan BP, Chan YW, Tian XY and Huang Y: Reactive oxygen species, endoplasmic reticulum stress and mitochondrial dysfunction: The link with cardiac arrhythmogenesis. Front Physiol 7: 313, 2016

147. Sun B, Chen Z, Gu J, Tse G, Jiang J, Huang F and Zhao C: Tight junction proteins and gap junction proteins play important roles in high fat dietary atherosclerosis pathogenesis. Int J Clin Exp Pathol 9: 7969-7976, 2016.

148. Tse G, Ali A, Prasad SK, Vassiliou V and Raphael CE: Atypical case of post-partum cardiomyopathy: an overlap syndrome with arrhythmogenic right ventricular cardiomyopathy? BJRIcase reports 1: 20150182,2015.

149. Tse G, Ali A, Alpendurada F, Prasad S, Raphael CE and Vassiliou V: Tuberculous constrictive pericarditis. Res Cardiovasc Med 4: e29614, 2015.

150. Mayosi BM, Ntsekhe M, Bosch J, Pandie S, Jung H, Gumedze F, Pogue J, Thabane L, Smieja M, Francis V, et al; IMPI Trial Investigators: Prednisolone and Mycobacterium indicus pranii in tuberculous pericarditis. N Engl J Med 371: 1121-1130, 2014.

151. Vassiliou V, Chin C, Perperoglou A, Tse G, Ali A, Raphael C, Jabbour A, Newby D, Pennell D, Dweck M and Prasad S: 93 Ejection fraction by cardiovascular magnetic resonance predicts adverse outcomes post aortic valve replacement. Heart 100 (Suppl 3): A53-A54, 2014

152. Tse G, Hothi SS, Grace AA and Huang CL: Ventricular arrhythmogenesis following slowed conduction in heptanol-treated, Langendorff-perfused mouse hearts. J Physiol Sci 62: 79-92, 2012.

153. Wong J, Tan T, Chan C, Laxton V, Chan Y, Liu T, Wong J and Tse G: The role of connexins in wound healing and repair: novel therapeutic approaches. Front Physiol 7: 596, 2016.

This work is licensed under a Creative Commons Attribution 4.0 International (CC BY 4.0) License. 